\title{
Pre-service English teachers' perceptions of their online teaching practice during pandemic times
}

\section{Percepciones de los profesores de inglés en formación sobre su práctica docente en línea durante tiempos de pandemia}

\section{Paola Julie Aguilar-Cruz}

Holds a Master degree in Education from Universidad de Medellin. She works as an English teacher at Jorge Eliécer Gaitán High School and Amazonia University. She is currently a PhD student in Educational Technology at Central China Normal University. Her research interests include multimodality, gamification and the use of educational technology for English language teaching and learning.

ORCID: https://orcid.org/0000-0001-8386-9104

\section{Deicy Lorena Medina}

Holds a Bachelor degree in English Language Teaching from Universidad Surcolombiana. Her research interests are ICT and its relation to pedagogy and education, literature and literacy.

ORCID: https://orcid.org/0000-0002-7300-0533

\section{*Correspondence}

Email: paolaaguilarcruz@gmail.com

\section{Cite as:}

Aguilar-Cruz, P.J., Medina, D.L. (2021). Pre-service English teachers' perceptions of their online teaching practice during pandemic times. Propósitos y Representaciones, 9 (SPE1), e925. Doi: http://dx.doi.org/10.20511/pyr2021.v9nSPE1.925 


\section{Summary}

This paper investigates pre-service English teachers' perceptions on their online teaching practice during pandemic times, focusing on issues related to technology, materials development and gamification. Accordingly, a qualitative narrative research approach was implemented to deeply inquiry pre-service English teachers through interviews and artifacts. It is concluded that even though pre-service English teachers had to face different concerns related to their online teaching practice, such as students' lack of commitment, low motivation and connectivity issues because of the pandemic, still they were capable of understanding and reflecting upon their role as teachers and used technology and gamified activities to overcome their concerns.

Key words: Technology for language teaching, Online teaching, COVID-19, Gamification, Materials Development.

\section{Resumen}

Este artículo investiga las percepciones de los profesores de inglés en formación sobre su práctica de enseñanza en línea durante tiempos de pandemia, centrándose en cuestiones relacionadas con la tecnología, el desarrollo de materiales y la gamificación. En consecuencia, se implementó un enfoque de investigación narrativa cualitativa para indagar profundamente a los profesores de inglés en formación a través de entrevistas y artefactos. Se concluye que a pesar de que los profesores de inglés en formación tuvieron que enfrentar diferentes preocupaciones relacionadas con su práctica docente en línea, como la falta de compromiso de los estudiantes, la baja motivación y problemas de conectividad debido a la pandemia, aún fueron capaces de comprender y reflexionar sobre su rol como docentes y utilizaron tecnología y actividades ludificadas para superar sus inquietudes.

Palabras clave: Tecnología para la enseñanza de idiomas, Enseñanza online, COVID-19, Gamificación, Desarrollo de materiales.

\section{Introduction}

The current pandemic human beings are facing has impacted educational processes in different ways. In the Colombian Amazon region this issue has been worse. As reported by RojasBahamón, et. al (2020) the strategies used by the Colombian government have generated serious consequences in the teaching and learning processes in Caquetá and the Amazon region, in which "problems of curricular fractionation came to light, the lack of appropriation of ICT by teachers, little or no access to information and communication technologies, among others" (p. 234). The previous excerpt relates some of the issues that teachers had to face, however, pre-service teachers in this region have had to deal with some more.

The Amazonia University is a highly recognized university in the Colombian Amazon region. Its English Language Teaching program (ELT) is recognized by its qualified pre-service teachers. Due to the pandemic, the university could not assign their pre-service students to schools where they perform the practice because schools in this region were not implementing neither online teaching nor face-to-face classes. To be able to offer pre-service teachers the chance of doing their teaching practice, the university offered free online English courses to students from any school along the county who wanted to join. After that, the university got an average of 15 students to assign to each pre-service teacher. This strategy implemented by the university has led to different results that will be related later.

In terms of technology and material development, research has demonstrated that the use of multimodal and interactive materials has had a significant impact in students' motivation and learning processes (García, et. al, 2011; Polyxeni \& Papadopoulou, 2013; Aguilar-Cruz, 2018, Mahmod, 2019). Regarding gamification, research highlights the current trends in implementing gamification and game strategies to enhance and improve students' learning (Buckley \& Doyle, 
2016; Solano, et. al, 2017; Tan, 2018; Aljraiwi, 2019; Lander, et al., 2019; Cooney \& Darcy, 2020). This article reports a qualitative narrative research process that aimed at describing preservice teachers' perceptions of their online teaching practice experience during pandemic times, focusing on issues related to technology, materials development and gamification.

\section{Theoretical Framework}

\section{Information and Communication Technology (ICT) for language learning}

The National Ministry of Education (MEN, henceforth) in Colombia issued the document ICT Competences for the Professional Teaching Development, which "portrays guidelines concerning the use of ICT resources for teaching purposes in the country" (Fernández, et. al, 2019, p.30). The document states five different moments or competences that every teacher should have: technological, pedagogical, communicative, management and investigative. The competences are national standards set in 2013 as a result of the upcoming challenges that education would face. However, even when teachers as well as the government and education itself recognize ICT as an important issue to be addressed, the reality has shown some discrepancies between the guidelines and the teachers' performances in their daily practices in the classroom.

Fernández, et. al, (2019) relate a series of research related to ICT carried out by preservice English teachers. In their systematization they highlight alternatives strategies in L2 teaching and learning, perceptions, and meanings of the use of ICT, and ICT skills that students teachers need to have. This embraces challenges for pre-service teachers in the Amazon region since access to technology and connectivity is a current issue.

\section{Materials Development}

Tomlinson (2003) states that materials can be anything that can be used to facilitate language learning. The author relates that materials can be linguistic, visuals, kinesthetic, and can also be printed, recorded, or posted on the internet. Overall, a learning material, in accordance with the author, must meet student' needs and likes. Similarly, Kitao and Kitao (1997) assume that learners should be the focus of the teaching and learning processes, in which materials development is an axis.

In line with the previous points of view, the MEN (2016) pinpoints that teaching materials must be a help to achieve learning goals and must include activities that integrate the four abilities (listening, speaking, reading and writing) to promote the use of language in real communicative contexts. Howard and Major (2004) consider that to develop high quality language teaching materials, teachers should take into consideration: the contextualization, know individuals' needs and interests, the personalization and the punctuality. Besides, Núñez, et al. (2004) agree that there are four requirements to design appropriate materials. These are: needs analysis, objectives, selection and sequence, learning and teaching activities, and assessment. The authors represent this process as a cyclic one, in which reflection allows improvement.

\section{Gamification}

Gamification, as asserted by Seaborn and Fels (2014) "is generally defined as the use of game elements and mechanics in non-game contexts" (p.16). In educational settings, game mechanics and dynamics are included as a way of gamifying the teaching and learning process. As proposed by Buckley and Doyle (2016) "in a gamified learning intervention, rules structure the learning activity, placing clear limits on the actions a learner can take. This makes it fundamentally different from free-form learning activities, such as essays, projects or presentations" (p.2). This entails that gamification must involve teachers' and students' interests and motivations. 
Cooney and Darcy (2020) explored the value of a game strategy as a pedagogical tool. The authors noted that gamification enhanced students' awareness of collaborative learning attitudes and gained confidence. This embraces that students were also able to reflect on their own performance and learning styles and strategies. Additionally, Lee and Hammer (2011) discussed that gamification is a way to motivate students to engage in classroom activities. They claimed that gamification "give teachers better tools to guide and reward students, and get students to bring their full selves to the pursuit of learning" (p.4), showing that learning can be a joyful experience.

\section{Methodology}

This research is considered within the qualitative research paradigm because, as expressed by Creswell (2009), it serves to explore and understand the meaning that individuals give to social and human issues. The author also supports that qualitative research is an interpretative process that examines and inquires a human or social problem. To do so, a narrative design was implemented. According to Creswell (2012) narrative research serves as a way to collect individual's stories and experiences. It is noted that "examining educational practices narratively is to view teaching as expressions of embodied personal and social stories, and to think of teachers as individuals who ought to be understood as such, but who are also always part of a social context" (Mendieta, 2013, p.145).

For this research, pre-service English teachers were asked to share their stories through a narrative interview, in which they also related the lesson plans they created as part of the requirements for the Teaching Practice II course. Their lesson plans were analyzed as artifacts, which Hernández et al. (2014) remark that can be any written or recorded document that serve to know the lived experiences of the participants.

Based on narrative research methods, participants were chosen under the condition of having taken the Teaching Practice I course and being enrolled in the Teaching Practice II course of the ELT program at Amazonia University. The seven participants were doing their Teaching Practice II in High-School level, specifically in 9th, 10th and 11th grade (see Table 1).

\begin{tabular}{|l|l|}
\hline Student Code & Grade \\
\hline S1 & 11 th \\
\hline S2 & 9 th \\
\hline S3 & 9 th \\
\hline S4 & 9th \\
\hline S5 & 9th \\
\hline S6 & 10 th \\
\hline S7 & 10 th \\
\hline
\end{tabular}

Table 1. Participants

Source: Designed by the authors.

All the students were studying their ninth semester of the ELT program, which means that they have already taken all the courses related to English language learning, classroom methodologies, pedagogy, materials design, among others. 
The data gathered from students' interviews and artifacts was recorded and analyzed as proposed by Creswell (2012) identifying themes or categories of information. The categories identified were codified and related in a research analysis matrix. Finally, a triangulation process among the interviews and the artifacts was carried out to find reliability and support students' narratives.

\section{Results and discussion}

The narrative research process led to three main findings about the online teaching practice that the pre-service English teachers developed during the pandemic. The first finding is related to pre-service teachers' concerns about their online teaching practice during the pandemic. The second is aimed at the role of technology in online teaching environments. The third entails the importance of materials development and gamification for teaching.

\section{Pre-service English teachers' concerns about their online teaching practice during the pandemic}

As stated in the introduction, because of the pandemic, Amazonia University had to offer free online English courses for any high school student who wanted to enroll. This methodology implemented by the university was not positively perceived by pre-service English teachers at the very beginning of the semester. The first concern was related to the fact that the teaching practice was going to be held online. As highlighted by one of the pre-service teachers:

The global situation that has made us teach remotely makes the teaching process increasingly difficult. I feel that there are many things that still need to be learned and that only in real practice with the students can this knowledge be acquired. (S3)

Pre-service English teachers declared they were frightened, tense, nervous and stressed about their online teaching process, some of them remarked:

I felt like I was in an amusement park since I could feel my emotions going up and down in any situation. (S1)

I was so nervous because it was my first session with ninth grade students who communicate from virtually all parts of Colombia. (S5)

That monday at night I could barely sleep since I was anxious and stressed about the class of the next day. (S4)

Some other pre-service teachers' concerns were related to students' attendance and commitment to the courses. Since it was a free course, many of the students did not seem to appreciate the value of it, as specified in the following transcripts of the interviews:

I was disconcerted by the fact that the students did not join the class on time. (S1)

Although, English courses are given free of charge to help people who need them, many situations arise that get out of hand and there are very few people with a real commitment to learning and attending the meetings. (S3)

It was hard to try to establish a connection with some, because I talked to some and they did not answer, I had no idea if they were there or if they had some problems with the internet. (S7)

Some students entered the platform very late so that I lost some time when explaining repeatedly what they were supposed to do. (S2)

It is sad to see students do not join the classes, even the fact that it is free. (S6) 
The previous transcripts relate the fact that students joined the meeting but did not talk or say anything during the whole class. This could also happen for different reasons such as: students' shyness, connectivity issues, and lack of interest and motivation, as supported by the pre-service English teachers in the interviews. In terms of commitment and students' lack of interest and motivation, participants added that:

Only nine of students showed up on the first day, and within ten minutes of starting one of the students left the meeting. (S3)

As I mentioned before, not all the students entered the meeting but fortunately, they typed on WhatsApp that they wanted to join the classes next week, but they didn't connect. (S2)

There are many excuses for not attending the classes. They didn't answer the calls or messages I sent to them. (S3)

The attendance of students is one of my concerns. I start the lesson with eight or six students and at the end of the session there are only three students. The lack of participation is remarkable considering that the process of calling parents and confirming their children's attendance to the English course has been done and they are still not connected to the class. (S3)

One problem was the students' attendance. In the first class, I had 12 students out of 18. (S6)

Even though students and parents had to sign an academic contract with the university, the students enrolled in the course did not seem to be interested in joining the classes. As stated by the participants, students presented different excuses for not participating in the online sessions such as medical issues, family problems and other commitments previously arranged. However, pre-service English teachers could not validate that all this information was true.

\section{Pre-service English teachers' perceptions of the role of technology in online language learning and teaching}

Warschauer (2005) expresses that technology must be seen as a means to promote language learning. However, many issues can arise from online teaching in a region like the Amazon, in which connectivity and lack of technological devices is a common factor. From the narrations of the pre-service English teachers advantages and drawbacks regarding the use of technology were claimed.

Regarding advantages, some participants related that:

The internet connection was very good and useful. The platform called ZOOM helped us too much since it is said that this platform is great. (S2)

Some of them told me that the use of the platforms were really cool and they wanted me to use them once again. (S3)

Pre-service English teachers became aware of the importance of having knowledge about technology use and its implementation in online teaching. In accordance with Fernández, et. al (2019) student teachers should have a full understanding of ICT resources so as to carefully integrate, "promoting students' critical thinking and interest for their learning" (p. 79).

In their research, Solano, et. al (2017) found out that the majority of students and teachers do not usually use technology during the class because 'the institution does not provide them with enough technological material and teachers are not sufficiently trained to use it on daily basis' (p.81). Fernández, et. al (2019) relates that most teachers end up including technology as fillers or to assist certain topics. Although this is true, having the technological devices, training and awareness of the role of technology in language teaching and learning, did not seem to be an issue for the pre-service English teachers. Nevertheless, the narratives declared drawbacks embraced 
connectivity issues and technical problems from both sides: pre-service English teachers and their students. As addressed by the participants:

In the first class some of my students could not join since they were having difficulties with the link that I provided them with. Furthermore, a student was also having issues with her microphone and she was unable to speak and participate actively. I asked her to write her comments and points of view in the chat of Zoom. There were also more problems and difficulties, another of my students was having internet connection issues and she was constantly connecting and disconnecting from the class. I am going to try a different platform for the next class since some of my students were not able to be in class. (S4)

I also felt very worried because where I live there is a constant connection failure and indeed in my first class the energy went away. However, I continued the activity that was interrupted by this problem, and the kids managed to participate in the WhatsApp chat. (S5)

I had some technical issues with the zoom platform. (S1)

One of the students expressed that she was having some problems with the platform of Zoom and for that reason, she could not neither talk nor participate in the classes. Thus, I asked the students if they could use another platform like "Google Meet", but some of them told me they could not. At the end of the class I talked to the student and we agreed to use other methods to see if it could work. Finally, the student tried on Thursday and we could notice that it worked. (S6)

The second session was very disturbed because of the connection and the Zoom platform was not working very well, so the class started a little bit late and I took so long to try to be understood. (S7)

Connection is definitively one of the biggest problems, but it is no one's fault. This problem caused that students could not understand what I was talking or vice versa. (S7)

Definitely, I am having some troubles with my computer because it sometimes stops working and the screen freezes. I have to format it, but I am afraid to lose all the information I keep there. (S7)

All the difficulties pre-service teachers faced led them to an understanding of how to solve teaching problems in online environments. It also gave them a glance of how their teaching in face-to-face contexts would be. As stressed by Walker and White (2013) "digital technologies not only create new environments in which language use occurs, they also bring together interlocutors who might not otherwise have opportunities to interact" (p.17). Accordingly,one of the issues that seemed to be the most important for the pre-service English teachers in terms of knowledge acquired is the fact of being able to deal with technological issues and carefully think and analyze how to solve them during the class session to communicate with their students.

The previously related pieces of evidence confirmed that "effective and efficient use of technology must be planned by teachers" (Egbert, 2005, p.174). In which participants' attitudes played a crucial role. Kessler (2007, quoted by Morales, 2015) argues that "if attitude is a significant indicator of ability, it seems that language teaching professionals are generally capable and confident in their use of technology" (p.51). This was evident in participants' attempts to solve the technological issues and confirmed what was highlighted by Cutajar (2019) who states that there is a disruption from the traditional teaching methods to the use of digital technologies to transform teaching.

\section{Pre-service English teachers' reflections upon materials development and gamification for online teaching}

As a result of the pandemic "students were exposed to different changes in the way they take classes" (Rojas-Bahamón, et. al, 2020, p.238). In their narratives, pre-service English teachers reflected upon how they were going to organize their lessons and what materials and methodologies they should use for online teaching. Overall, they addressed that gamified 
activities were the most suitable ones for online teaching. They agreed upon using ClassDojo as a way to support gamification of learning, as mentioned by this participant:

ClassDojo is the best application I have found. They (students) all want to get their badges. They seem to be very interested and even if they can't attend the class, they want to develop the class activities so they can get their points on the platform. The platform allows teachers to give feedback, which is also important in the online learning process. Students can follow their progress. I can now say that the idea of using an app for the class and motivating the students through gamification can be a good strategy. (S6)

Solano, et. al (2017) add that there is a need to 'integrate technology tools combined with appropriate teaching strategies in EFL classrooms' (p.77). Hence, pre-service English teachers also implemented additional activities like bingos, tic-tac-toe, songs, Google Maps, Quizizz, Kahoot and Pear Deck through collaborative learning activities. They commented:

The students had the opportunity to talk about their favorite song and taking into account that it was a topic prepared in advance, they feel less anxious and more eager to participate and socialize their chosen song with their peers. (S3)

We travelled to many different countries by means of google maps and I could notice they are interested in European countries and do not feel interested at all in America, I asked some question and they told me that they like different things since here in Colombia people is almost equal. (S4)

The Pear Deck slides were too useful, and I could evidence how my students were understanding each part of the tense without explaining them directly (S6)

The activity of writing about the artist in pairs was good since I could create the rooms in the Zoom platform and make them work during the class. In this part, I confirm they like to work in pairs, and they can make tasks faster. (S6)

Likewise participants also reflected upon their teaching process, showing their deep understanding of their role as future teachers. They mentioned:

I have tried to give my best, making the classes fun, creating creative material among other things. All the difficulties that I have faced regarding technology made me reflect on the different teaching strategies I used and I believe that this will motivate me to improve. (S5)

Bates (2015) agrees that "traditional classroom teaching, and especially transmissive lectures, were designed for another age, we are now in a different age that requires different methods" (quoted by Cutajar, 2019, p. 2). This age requires teachers who are aware of their role in online language teaching and learning processes. Ajustado a la plantilla.

\section{Conclusions}

The pre-service English teachers' narratives assert that having an online teaching practice during the pandemic lockdown has advantages and it also involves some drawbacks. Participants' concerns were mainly related to their negative feelings regarding the online teaching practice and their students' commitment and motivation towards the online classes. In the same line, preservice English teachers' perceptions of the role of technology for online teaching embraced connectivity issues and awareness of the importance of technology for communication and learning. Technology was found to be a crucial factor in the teaching process because without it, it would have not been possible to offer the participants the chance of doing their teaching practice during 2020. The pandemic allowed pre-service teachers to reflect upon their teaching process and be aware of their role as future teachers. Finally, gamified teaching materials were found to be a highly positive strategy to be implemented for online teaching in which collaborative learning and team work had beneficial outcomes. 


\section{References}

Aguilar-Cruz, P. J. (2018). Herramienta multimodal basada en tareas para el aprendizaje del inglés en el grado sexto en Florencia, Caquetá (Colombia). Ciencias Sociales y Educación, 7(14), 65-83. DOI: https://doi.org/10.22395/csye.v7n14a4

Aljraiwi, S. (2019). Effectiveness of Gamification of Web-Based Learning in Improving Academic Achievement and Creative Thinking among Primary School Students. International Journal of Education and Practice, 7 (3), 242-257.

Buckley, P.; \& Doyle, E. (2016). Gamification and Student Motivation. Interactive Learning Environments, $\quad 24 \quad$ (6), 1162-1175. http://dx.doi.org/10.1080/10494820.2014.964263

Cooney, A.; and Darcy, E. (2020). 'It was fun': Exploring the pedagogical value of collaborative educational games. Journal of University Teaching \& Learning Practice, 17(3), 2020. Available at: https://ro.uow.edu.au/jutlp/vol17/iss3/4

Creswell, J. (2009). Research Design. Qualitative, Quantitative, and Mixed Methods. Los Ángeles: University of Nebraska-Lincoln, Sage.

Creswell, J. (2012). Educational Research: Planning, Conducting, and Evaluating Quantitative and Qualitative Research. London: Pearson.

Cutajar, M. (2019). Teaching Using Digital Technologies: Transmission or Participation?. Education Sciences, 9 (226), 1-13.

García, D., García, J., \& Hernández, Y. (2011). Students' beliefs: Multimodal Texts as Pedagogical Tools in Foreign Language Learning. Revista Papeles, 3(5), 21-35.

Fernández, F., Monje, C., Alarcón, E., Medina, D., Gonzales, O., Marles, E., Gonzáles, F. \& González, A. (2019). ICT Experiences in Surcolombiana University: classroom research systematization in initial and teacher training. Neiva: Editorial Universidad Surcolombiana.

Hernández Sampieri, R., Fernández Collado, C., \& Baptista Lucio, P. (2014). Metodología de la Investigación. México: McGRAW-HILL / INTERAMERICANA EDITORES, S.A. DE C.V.

Howard, J., \& Major, J. (2004). Guidelines for designing effective English language teaching materials. 9th Conference of Pan Pacific Association of Applied Linguistic Conference. 101-109. Obtenido http://www.paaljapan.org/resources/proceedings/PAAL9/pdf/Howard.pdf

Lee, J. J. \& Hammer, J. (2011). Gamification in Education: What, How, Why Bother? Academic Exchange Quarterly, 15(2), 1-5.

Kitao, K., \& Kitao, S. (1997). Selecting and Developing Teaching/Learning Materials. The Internet TESL Journal, IV (4), 1-4. Obtenido de http://iteslj.org/Articles/KitaoMaterials.html

Mahmod, A. (2019). How Technology Affects Language Learning and Teaching. International Scientific Journals IJEISR, 3 (1), 1-7. DOI: 10.31219/osf.io/m3jx6 
Mendieta, J. (2013). Narrative research: An alternative approach to study language teaching and learning. FOLIOS, 30, 135-147.

Ministerio de Educación Nacional. (2016). Orientaciones y Principios Pedagógicos. Currículo Sugerido de inglés. Grados $6^{\circ}$ a $11^{\circ}$. English for Diversity and Equity. Recuperado el 06 de Marzo de 2017, de Colombia Aprende: http://aprende.colombiaaprende.edu.co/sites/default/files/naspublic/Anexo\%2014\%20O rientaciones\%20y\%20principios\%20Pedagogicos.pdf

Morales, S. (2015). How in-service language teachers become effective users of CALL for online teaching and learning: A case study of their development processes in a transformative online teacher training and development course. Thesis Submitted for the Degree of Doctor of Philosophy Integrated Ph.D. in Educational and Applied Linguistics. Newcastle University. School of Education, Communication and Language Sciences. From: https://theses.ncl.ac.uk/jspui/handle/10443/3009

Núñez, A., Pineda, C., \& Téllez, M. (2004). Key Aspects for Developing Your Instructional Materials. PROFILE, 5(1), 128-139.

Polyxeni, M., \& Papadopoulou, M. (2013). Greek Students' Familiarity with Multimodal Texts in EFL. The Internacional Journal of Literacies, 19(1), 37-46. Recuperado el 11 de Octubre de 2017, de http://thelearner.com/

Rojas-Bahamón, M.J; Aguilar-Cruz, P.J. y Arbeláez-Campillo, D.F. (2020). Curricular integration as a strategy to strengthen the educational process in public institutions in COVID-19 times. Revista Inclusiones Vol 7 num Especial, 233-241.

Seaborn, K \& Fels, D. (2014). Gamification in theory and action: A survey. Int. J.HumanComputerStudies, 74, 14-31. DOI: http://dx.doi.org/10.1016/j.ijhcs.2014.09.006

Solano, L; Cabrera, P; Ulehlova, E \& Espinoza, V. (2017). Exploring the use of educational technology in EFL teaching: a case study of primary education in the south región of Ecuador. Teaching English with Technology, 17(2), 77-86.

Tan, Y.L.L. (2018). Meaningful gamification and students' motivation: A strategy for scaffolding reading material. Online Learning, 22(2), 141-155. DOI: 10.24059/olj.v22i2.1167

Tomlinson, B. (2003). Developing Materials for Language Teaching. Gran Bretaña: Croomwell Press, Trowbridge, Wilsthire.

Walker, A \& White, G. (2013). Technology Enhanced Language Learning: Connecting theory and practice. London: Oxford. 